\title{
A high sensitivity nitrate reductase assay and its application to vertically migrating Rhizosolenia mats
}

\author{
Leanne Joseph ${ }^{1}$, Tracy A. Villareal ${ }^{1, *}$, Fred Lipschultz ${ }^{2}$ \\ 'Environmental Sciences Program, University of Massachusetts, 100 Morrissey Blvd, Boston, Massachusetts 02125-3393, USA \\ ${ }^{2}$ Bermuda Biological Station for Research, Inc., Ferry Reach, GE01, Bermuda
}

\begin{abstract}
A high sensitivity assay for nitrate reductase (NR) was developed that permitted determination on samples as small as $0.2 \mu \mathrm{g}$ chlorophyll a. We combined a revised NR assay chemistry with chemiluminescent determination of nitrite to improve sensitivity approximately 50 -fold over colorimetric techniques. Results from colorimetric and chemiluminescent techniques were linearly related $\left(r^{2}=\right.$ $0.96, p=0.0001$ ). The NR assay reagents did not interfere with chemiluminescent nitrite determinations although the reagents did contain detectable amounts of nitrite. The assay chemistry and incubation temperature required optimization for our species. We used the assay to measure NR rates in macroscopic Rhizosolenia mats from the North Pacific Ocean. Rates were adequate to support calculated nitrogen demands of mats. Floating mats had significantly higher NR activity and internal nitrate pools than sinking mats, providing more evidence to support the hypothesis that these pelagic diatoms can migrate below the nutricline to exploit deep nitrate pools and then return to the surface for photosynthesis.
\end{abstract}

KEY WORDS: Nitrate reductase Chemiluminescence - Vertical migration - Rhizosolenia mat. Diatom

\section{INTRODUCTION}

Nitrogen is generally accepted to be the nutrient most often limiting to marine phytoplankton (Ryther \& Dunstan 1971, McCarthy \& Carpenter 1983). The availability of different nitrogen sources, uptake rates, and assimilation rates are important regulators of phytoplankton growth. Examination of the enzymes involved in nitrogen assimilation has been one approach for determining nitrogen utilization, particularly for inducible enzyme systems. The presence of these inducible pathways is often diagnostic for specific forms of nitrogen, and can reveal important data on nutrient prehistory and life history strategies when combined with other markers. In this paper, we use these concepts to examine the nutrient utilization patterns of vertically migrating diatom mats from the central North Pacific Ocean.

\footnotetext{
·Addressee for reprints.E-mail: villareal@umbsky.cc.umb.edu
}

Assimilatory nitrate reductase (NR) is an inducible enzyme in photoautotrophs, including phytoplankton, that catalyzes the reduction of nitrate $\left(\mathrm{NO}_{3}{ }^{-}\right)$to nitrite $\left(\mathrm{NO}_{2}{ }^{-}\right)$. Eppley et al. (1969) developed a method of measuring NR activity in phytoplankton, and concluded that the assay was useful as a positive indicator of the nitrogen source being used, although it was unsatisfactory for quantitative measurement of nitrate incorporation. Since then, various studies have sought to extend the usefulness of the NR assay by investigating the regulation of NR and the effects of various environmental conditions on NR activity. NR activity responds to the internal cellular concentration of nitrate rather than the ambient water concentration (Collos \& Slawyk 1976, 1977, Dortch et al. 1979), and is inhibited in cells grown on ammonia or in nitrate-grown cells in the presence of ammonia levels as low as 0.5 to $1 \mu \mathrm{M}$ (Eppley et al. 1969, Packard \& Blasco 1974). It exhibits light dependence and diel periodicity (Packard 1973, Hersey \& Swift 1976, Martinez et al. 1987, Ramalho et al. 1995), as well as temperature sensitivity (Gao et al. 1993). 
Numerous efforts to define the relationship between nitrate uptake and NR activity have revealed that the uptake and reduction of nitrate are frequently uncoupled (Collos \& Slawyk 1977, Dortch et al. 1979, Blasco et al. 1984). Skeletonema costatum, a species of diatom that has a capacity for nitrate storage, displays internal pool utilization during and after the depletion of external nitrate, allowing the species to maintain high rates of reduction at low external nitrate levels (Dortch et al. 1979). After observing variation in the uptake:reduction ratio in an upwelling region off of Peru, Blasco et al. (1984) proposed that uptake is more sensitive to environmental changes than reduction. These results suggest that internal nitrate pools can provide a buffer against fluctuating nutrient concentrations

Our objective was to determine whether the large internal nitrate pools present in Rhizosolenia mats in the North Pacific gyre are their primary nitrogen source. These mats are multi-species assemblages up to $30 \mathrm{~cm}$ in diameter formed by species of the marine diatom genus Rhizosolenia (Venrick 1969, Carpenter et al. 1977). Intertwining chains of $R$. fallax, a small diameter $(10$ to $20 \mu \mathrm{m}$ ) species, form the matrix of the mats with numerous large celled Rhizosolenia species (diameter 50 to $250 \mu \mathrm{m}$ ) imbedded in the matrix (Villareal \& Carpenter 1989). Although fewer in number, these large cells account for all but a few percent of the total biovolume (Villareal \& Carpenter 1989, Villareal et al. 1996). Mats exhibit strong positive buoyancy, an obvious advantage for their survival in oceanic water where the euphotic zone extends to only a few percent of the water column depth. However, the larger size of Rhizosolenia cells reduces their ability to acquire nutrients that are present in very low concentrations due to a lower surface area to volume (s/v) ratio than smaller species (Chisholm 1992). Rhizosolenia mats, and probably most large, nonmotile, oceanic phytoplankton, overcome this problem by migrating vertically to the nutricline where they acquire nitrate before returning to the surface to photosynthesize (Villareal et al. 1993, Villareal \& Lipschultz 1995). Mats exhibit both positive and negative buoyancy, with positively buoyant mats containing significantly higher internal nitrate concentrations than negatively buoyant mats. In addition, mats have a $\delta^{15} \mathrm{~N}$ isotope signature distinct from other ambient phytoplankton, but typical of the deep nitrate pool (Villareal et al. 1993).

We hypothesized that, if nitrate was their primary nitrogen source, we would detect high and variable NR activity in Rhizosolenia mats floating in the surface water. Similarly, we expected to find very low or no activity in sinking mats. Confirmation of these hypotheses would provide further evidence of vertical migration. We also wanted to examine whether
NR activity would provide a useful indicator of the growth rate of mats. Dortch et al. (1979) concluded that $\mathrm{NR}$ activity can approximate $\mathrm{NO}_{3}^{-}$assimilation rate under certain conditions, including after $\mathrm{NO}_{3}$ additions when external $\mathrm{NO}_{3}{ }^{-}$uptake rates decline to low levels. Collos \& Slawyk (1976) reported that NR activity is positively correlated with increasing internal $\mathrm{NO}_{3}{ }^{-}$concentrations, and concluded that 'NR activity can account for the decrease of directly measured internal nitrate' and that the 'in vitro enzyme activity is equal to the in vivo rate' as long as no other nitrogen uptake is occurring. Nitrate and ammonia are present in the surface water of the North Pacific gyre in very low concentrations. Therefore, if nitrate uptake is occurring at depth, the NR activity of mats collected in the surface water should be a legitimate estimator of $\mathrm{NO}_{3}{ }^{-}$assimilation, and a minimum estimate of total nitrogen incorporation. Even so, diel variations must be taken into account before using measured rates to calculate natural population growth rates.

To test these hypotheses, it was necessary to be able to measure the NR activity of individual mats. The NR assay outlined by Eppley (1978) remains the standard at present, although there have been some modifications (Collos \& Lewin 1974, Scholl et al. 1974, Slawyk \& Collos 1976, Hochman et al. 1986, Berges \& Harrison 1995). All versions of the assay to date have relied on colorimetric nitrite determination, which imposes the greatest limitation on this method. Eppley (1978) placed the lower limit of detection at approximately $2 \mathrm{nmol} \mathrm{NO}{ }_{2}^{-}$per $10 \mathrm{ml}$ sample $(0.20 \mu \mathrm{M})$. The revised assay used in the present study (Berges \& Harrison 1995) produces a final sample volume of $3 \mathrm{ml}$. For a $2 \mathrm{nmol} \mathrm{NO}_{2}^{-}$yield, the final concentration is $0.7 \mu \mathrm{M}$, and $\mathrm{NO}_{2}{ }^{-}$concentration differences of $\leq 0.7 \mu \mathrm{M}$ are not resolvable in a $1 \mathrm{~cm}$ path length spectrophotometer cell.

To obtain a strong and reliable signal, Eppley (1978) suggests that at least $10 \mu \mathrm{g}$ of chlorophyll a (chl a) should be used. We wished to assay the mats individually to distinguish differences in NR activity between floating and sinking mats, and to study diel variations. However, Rhizosolenia mats contain only $\pm 1 \mu \mathrm{g}$ chl a or less (Alldredge \& Silver 1982, Villareal et al. 1996). This paper presents a revised protocol for examining NR that combines a revised reagent mixture with chemiluminescent determination of nitrite, providing a 50 -fold increase in sensitivity. Our method builds on previous research and permits the determination of enzyme activity in individual Rhizosolenia mats. We describe the methods and present results on the compatibility of combining the techniques. The optimal conditions for assaying Rhizosolenia mats and the NR activity of the mats, including evidence for diel fluctuations, are presented as well. 


\section{MATERIALS AND METHODS}

Laboratory experiments used Rhizosolenia setigera Brightwell cultures (clone RS1A) isolated from Cape Cod Bay, USA, in February 1994. Cells were grown in $\mathrm{f} / 10$ medium (with $\mathrm{f} / 5$ silicate) at $14^{\circ} \mathrm{C}$ under a $12: 12 \mathrm{~h}$ light:dark cycle $\left(95 \mu \mathrm{E} \mathrm{m}^{-2} \mathrm{~s}^{-1}\right)$. Field work was carried out on the RoMP 95 cruise of the RV 'Moana Wave' in the North Pacific in August of 1995, on a transect west from Hawaii along $28^{\circ} \mathrm{N}$ from $162^{\circ} \mathrm{W}$ to $173^{\circ} \mathrm{W}$, returning along $25^{\circ} \mathrm{N}$. Surface water temperature was 25 to $26^{\circ} \mathrm{C}$. Surface $\mathrm{NO}_{3}{ }^{-}$concentrations were always $<30 \mathrm{nM}$ and generally $\leq 5 \mathrm{nM}$ (Lipschultz unpubl. data).

Rhizosolenia mats from the upper $15 \mathrm{~m}$ of the water column were hand-collected in $500 \mathrm{ml}$ and $1 \mathrm{l}$ wide mouth polycarbonate bottles by SCUBA divers. The bottles were kept in a shaded insulated chest on deck for a time sufficient to allow the mats to rise or sink the height of the bottles ( $<30 \mathrm{~min}$ ). Mats were then sorted by visual inspection into 'floaters' or 'sinkers' if they were contacting either the top or the bottom of the bottles, or 'neutrals' if they had not clearly reached one of these boundaries. Mats were then either sampled immediately or incubated on deck in flowing surface water $\left(27\right.$ to $28^{\circ} \mathrm{C}$ ) and $50 \%$ incident light level for 2 to $18 \mathrm{~h}$ to examine diel variations in NR activity.

For sampling, each mat was pipetted to a graduated cylinder and raised to a known volume $(25 \mathrm{ml})$ using sea water from the collection jar. This volume was then transferred to a small capped plastic bottle, and the mat was dispersed by gentle inversion of the bottle to create a homogenous slurry of cells. This slurry was sampled for cell counts, biovolume determination, chl $a$, and internal nitrate concentration (INC). The remaining volume $(17 \mathrm{ml})$ was assayed for NR activity.

For cell counts and biovolume determination, $3 \mathrm{ml}$ of the cell slurry was preserved with formalin. Cells were counted in a $1 \mathrm{ml}$ Sedgewick-Rafter cell. Biovolume was determined, assuming cylindrical shape, by measuring at least 20 small cells per sample and all large cells present. $\mathrm{Chl}$ a was determined by filtering a $2 \mathrm{ml}$ sample of the slurry onto a Whatman GF/C filter and extracting in methanol. Concentrations were read on a Turner Fluorometer Model 10-AU using a non-acidification technique (Welschmeyer 1994).

For INC, a $1.0 \mathrm{ml}$ sample was frozen for no more than $3 \mathrm{~d}$, then boiled to lyse the cells. A chemiluminescent technique (Villareal \& Lipschultz 1995) was used to measure nitrate content (see below) and concentrations were determined by normalizing to biovolume. Usually $50 \mu \mathrm{l}$, and no more than $500 \mu \mathrm{l}$, per sample was analyzed for INC, and contained no more than 1.5 to 15 pmol of $\mathrm{NO}_{3}{ }^{-}$carried over from surface water. Since the nitrogen detector was operating at a threshold sen- sitivity of about 100 pmol, all detectable nitrate was attributed to internal cellular pools. We encountered nitrate contamination by several brands of cryovials, and mat INCs from the first two-thirds of the experiments were possibly overestimated by 0.04 to $1.65 \mathrm{mM}$ (based on average mat biovolume). These values will be indicated where used. Eppendorf microcentrifuge tubes did not contaminate our samples and were used for the remaining INCs. The problematic vials were used only for INC sample storage and did not affect any other analyses.

The enzyme extraction and NR assay were a modification of Berges \& Harrison (1995) up to the end product $\left(\mathrm{NO}_{2}^{-}\right)$determination. We found a ground glass tissue grinder was more efficient than a glassTeflon grinder in the small volume used. Centrifuge tubes and tube buckets were kept chilled in place of a refrigerated centrifuge. Other variations were in the concentration of $\mathrm{KNO}_{3}$ and the use of FAD (flavin adenine dinucleotide) as described below, and represent species-specific optimizations. All reagents were obtained from Sigma Chemical Company.

The cells were filtered through a $25 \mathrm{~mm}$ Whatman $\mathrm{GF} / \mathrm{C}$ glass fiber filter and ground in $1.0 \mathrm{ml}$ of extract buffer with a manual ground glass tissue grinder held in an ice water bath. The extract buffer consisted of a $200 \mathrm{mM}$ phosphate buffer, $\mathrm{pH} 7.9$, containing $0.03 \%$ $(\mathrm{w} / \mathrm{v})$ dithiothreitol (DTT), $0.3 \%(\mathrm{w} / \mathrm{v})$ polyvinyl pyrrolidone (PVP), $0.1 \%(\mathrm{v} / \mathrm{v})$ Triton X-100, $5 \mathrm{mM}$ ethylenediaminetetraacetic acid (EDTA), and $3 \%(\mathrm{w} / \mathrm{v})$ bovine serum albumin (BSA). The phosphate buffer had been pre-made and frozen (for no more than $1 \mathrm{mo}$ ), and the extract buffer was made fresh daily by addition of pre-weighed reagents. After grinding, the homogenized suspension was transferred to a chilled centrifuge tube and centrifuged at $750 \times \mathrm{g}$ for $5 \mathrm{~min}$. A fraction of the supernatant (100 to $400 \mu l)$ was then pipetted to a clean centrifuge tube to be assayed for enzyme activity. A second tube with an equal volume provided a time zero control. Frequently, a third tube containing an equal volume of plain extract buffer was run with the samples as a reagent blank. Reduced nicotinamide adenine dinucleotide (NADH), $\mathrm{FAD}$, and $\mathrm{KNO}_{3}$ solutions were made up fresh daily in $200 \mathrm{mM}$ phosphate buffer, $\mathrm{pH} 7.9$, to concentrations of $2,0.5$, and $200 \mathrm{mM}$, respectively. To each of the centrifuge tubes $100 \mu \mathrm{l}$ each of NADH and FAD was added, along with $200 \mathrm{mM}$ phosphate buffer, to yield a volume of $750 \mu \mathrm{l}$. The reaction was initiated by adding $250 \mu \mathrm{l}$ of $\mathrm{KNO}_{3}$. The volume of the reaction mixture was $1 \mathrm{ml}$, containing final concentrations of $0.2 \mathrm{mM} \mathrm{NADH}, 0.05 \mathrm{mM} F A D$, and $50 \mathrm{mM} \mathrm{KNO}_{3}$. In laboratory experiments using a local cold water clone of Rhizosolenia setigera, a cosmopolitan species, the same method was used, but final concentrations were 
$0.1 \mathrm{mM}$ NADH, $0.05 \mathrm{mMFAD}$, and $10 \mathrm{mM} \mathrm{KNO}_{3}$, and the reaction was run at $14^{\circ} \mathrm{C}$.

The time zero reaction was stopped immediately by the addition of $2.0 \mathrm{ml}$ of $550 \mathrm{mM}$ zinc acetate. The second tube and the reagent blank were incubated for $45 \mathrm{~min}$ at $22^{\circ} \mathrm{C}$ before termination. A time course experiment showed the reaction was linear up to $1 \mathrm{~h}$. The tubes were then centrifuged to clarify, and the supernatant was frozen in glass vials for later determination of nitrite. Although sample clarification is not required for the chemiluminescent chemistry, this step minimizes clogging of the syringe and permits comparison between chemiluminescent and colorimetric measurement of samples.

Chemiluminescence can be used to measure nanomolar concentrations of nitrate, nitrite or both combined (Garside 1982). The nitrogen form of interest is selectively reduced to nitric oxide (NO) which is then moved through the system by an inert carrier gas. Internal nitrate pools were determined using reagents that reduced both nitrate and nitrite to NO, as nitrite was not detected in the cells. Ferrous ammonium sulfate $(1.2 \mathrm{~g})$ and ammonium molybdate $(0.6 \mathrm{~g})$ were added to $150 \mathrm{ml}$ of phosphoric acid in a $300 \mathrm{ml}$ reaction flask and brought to $200-250 \mathrm{ml}$ with Nanopure deionized water (Villareal \& Lipschultz 1995). The reagents $\left(90^{\circ} \mathrm{C}\right)$ were flushed with either nitrogen or argon gas and mixed continuously with a stir bar. For nitrite determination, the reaction flask (room temperature) contained $20 \mathrm{ml}$ of a $3 \%$ sodium iodide solution, $60 \mathrm{ml}$ glacial acetic acid, and enough deionized water to raise the volume to $200-250 \mathrm{~m}$. The reaction is specific for $\mathrm{NO}_{2}^{-}$, and test blanks found no sensitivity to $\mathrm{NO}_{3}{ }^{-}$in the assay mixture. The $\mathrm{NO}_{2}{ }^{-}$reagents were those listed in Garside (1982).

Samples were injected into the reaction flask through a serum stopper. The resulting NO was flushed out of the flask and through an ice trap, an acid vapor trap of $\mathrm{NaOH}$ pellets, a calcium carbonate drying trap, and a vacushield filter by either $99.99 \% \mathrm{~N}_{2}$ or argon before entering the nitrogen oxides detector (Antek 720 ). Using this method we were able to run 10 to $15 \mathrm{sam}$ ples per hour. Injecting a $1 \mathrm{mi}$ sample we could detect nitrite concentrations at or above $100 \mathrm{nM}(\geq 100 \mathrm{pmol}$ of $\mathrm{NO}_{2}{ }^{-}$.

Because Rhizosolenia mats contain multiple species and different sizes of cells, NR activity was normalized

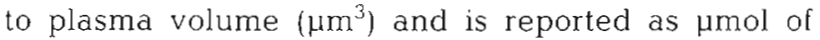
$\mathrm{NO}_{2}$ - formed per $\mu \mathrm{m}^{3}$ per hour. Plasma volume the cytoplasmic volume plus the nuclear volumel provides a more accurate estimate of metabolically active tissue than does cell number or total cell volume. Cytoplasmic volume was calculated as surface area $\times 1 \mu \mathrm{m}$. Previous guidelines for estimating cytoplasmic layer thickness based on the s/v ratio (Smayda 1978) would propose a thickness of $2 \mu \mathrm{m}$ for both small and large Rhizosolenia mat cells. However, microscopic measurements suggest that $1 \mu \mathrm{m}$ is a more reasonable estimate. Nuclear volume was measured for 4 cells ranging in diameter from 18 to $200 \mu \mathrm{m}$. An equation was fit between cell radius and nuclear volume using the curve fitting routine in DeltaGraph 3.5 .3 (DeltaPoint, Inc.), which was nuclear volume $=$ cell radius r $^{2.04} \times 5.72$ $\left(\mathrm{r}^{2}=0.995\right)$. This equation was used for all plasma volume calculations.

Prior to the field work, we assayed Rhizosolenia setigera for NR activity, and immediately measured the nitrite produced by both colorimetric and chemiluminescent techniques to determine if the reagents used in the enzyme assay would interfere with the chemiluminescent nitrite measurement. Colorimetric determination of nitrite was performed according to Berges \& Harrison (1995). $0.5 \mathrm{ml}$ of the supernatant was transferred to a $1 \mathrm{~cm}$ cuvette, and $20 \mu \mathrm{l}$ of $125 \mu \mathrm{M}$ phenazine methosulfate was added to oxidize excess $\mathrm{NADH}$. After $20 \mathrm{~min}$, the color was developed by adding $0.5 \mathrm{ml}$ of sulfanilamide solution and, within $5 \mathrm{~min}, 0.5 \mathrm{ml}$ of $\mathrm{N}$-(1-napthyl)-ethylenediamine $2 \mathrm{HCl}$ solution. Absorbance was then measured at $543 \mathrm{~nm}$.

Rhizosolenia mats were pooled for the time series and in initial assays to optimize the temperature and concentrations of $\mathrm{NADH}, \mathrm{FAD}$, and $\mathrm{KNO}_{3}$. The final samples from the temperature and FAD experiments were measured for nitrite by both colorimetric and chemiluminescent techniques.

\section{RESULTS}

The reproducibility of chemiluminescent measurements for all experiments was good, with duplicate injections for individual mat assays typically varying by less than $7 \%$.

NR assays comparing nitrite measurements by both colorimetric and chemiluminescent techniques compared favorably over a range of conditions (Fig. 1). NR activity was assayed on a volume of Rhizosolenia setigera culture equal to $28.5 \mu \mathrm{g} \mathrm{chl} a_{\text {, }}$ using both $100 \mu \mathrm{l}$ and $200 \mu \mathrm{l}$ of the same extract, and on samples of pooled mats, using various FAD concentrations and assay temperatures. NR activities as determined by the 2 methods were in good agreement $\left(r^{2}=0.959, p<0.0001\right)$. The slope (0.62) was significantly different than 1, but this may have been due to the inability to detect low levels of activity using colorimetric techniques.

Time zero controls for initial assays showed no detectable nitrite when measured colorimetrically. However, the chemiluminescent technique detected traces of nitrite in all controls and reagent blanks. Analysis of the assay reagents confirmed that the low 


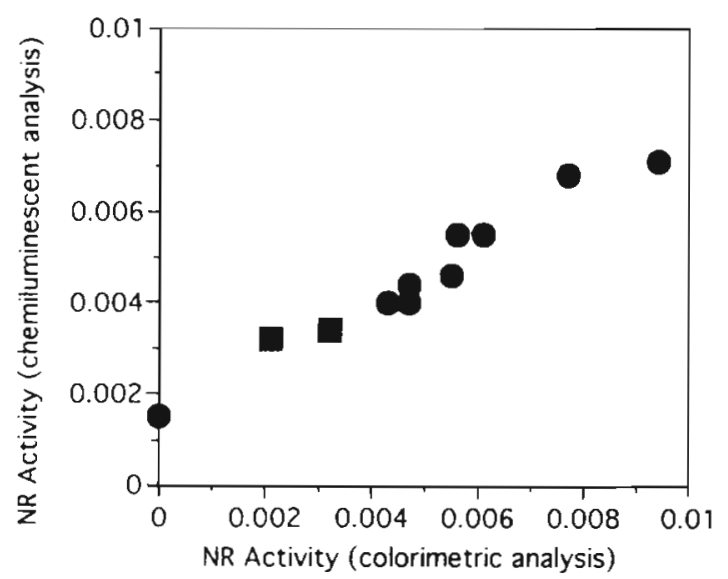

Fig 1 Comparison of NR (nitrate reductase) activity ( $\mu \mathrm{mol}$ $\mathrm{NO}_{2} \mu^{-1} \mathrm{chl} \mathrm{a} \mathrm{h}^{-1}$ ) in assays with nitrite determination by spectrophotometer and by chemiluminescent technique.

(ロ) Rhizosolenia setıgera assay; (-) Rhizosolenia mat assays

levels of nitrite measured in these blanks could be accounted for by the extract buffer components (Table 1). This slight contamination was corrected for by subtracting the time zero concentration from the final sample concentration.

The results of time series experiments performed on a pooled sample of 4 Rhizosolenia mats and on cultures of $R$. setigera (Fig. 2) showed the reaction to be linear up to $1 \mathrm{~h}$ in mats, and up to $30 \mathrm{~min}$ in $R$. setigera. The mat assay was run at room temperature in final concentrations of $0.1 \mathrm{mM} \mathrm{NADH}, 0.05 \mathrm{mM} \mathrm{FAD}$, and $10 \mathrm{mM} \mathrm{KNO}_{3}$ Subsequent mat assays were run for $45 \mathrm{~min}$. R. setigera assay conditions were as described in 'Materials and methods'.

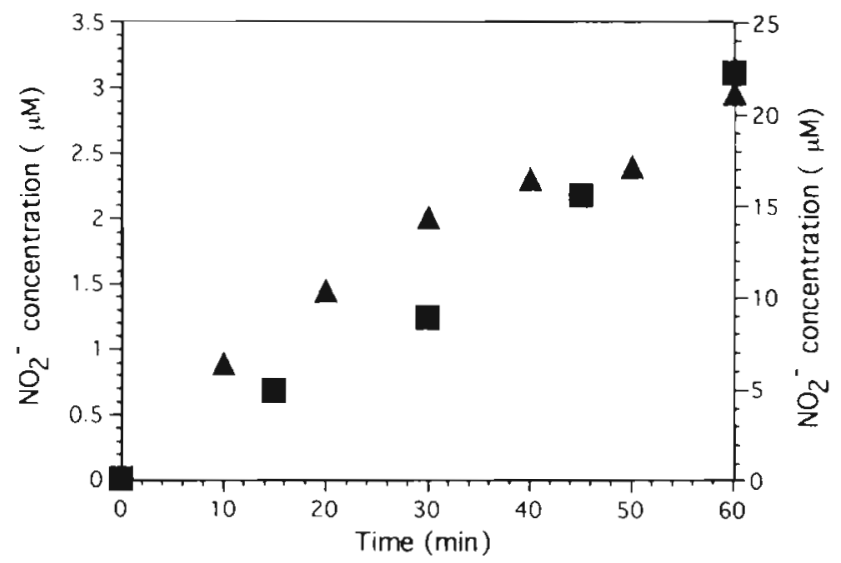

Fig. 2. Time series of NR activity in Rhizosolenia mats ( left $y$-axis) and $R$. setigera culture ( $\boldsymbol{\Delta}$, right $y$-axis). Rhizosolenia mats: $\mathrm{r}^{2}=0.988(0 \text { to } 60 \mathrm{~min})_{i} R$. setigera: $\mathrm{r}^{2}=0.990$ (for 0 to 30 min data points only)

After finding that the assay was sensitive to temperature (NR2; Fig. 3), a second pooled sample of Rhizosolenia mats (NR3; Fig. 3) was run in a cold incubator $\left(8^{\circ} \mathrm{C}\right)$, at room temperature $\left(22^{\circ} \mathrm{C}\right)$, and in an incubator on deck ( 27 to $28^{\circ} \mathrm{C}$ ). The optimal temperature of those available to us in the field was room temperature. Rates decreased by $20 \%$ at $8^{\circ} \mathrm{C}$ and 20 to $35 \%$ at 27 to $28^{\circ} \mathrm{C}$.

Examination of $\mathrm{FAD}, \mathrm{NADH}$, and $\mathrm{KNO}_{3}$ over a range of concentrations illustrated NR activity dependence on substrate concentration. When assayed using $0.1 \mathrm{mM}$ $\mathrm{NADH}$ and $10 \mathrm{mM} \mathrm{KNO}_{3}$, the addition of FAD increased activity 3 -fold over the assay with no FAD (Fig. 4A). With no addition of FAD, activity was undetectable by colorimetric techniques. In the presence of

Table 1. Nitrite content of NR assay reagents measured by chemiluminescence (with standard deviation of duplicate injections in parentheses), and average value of reagent blank $\pm \mathrm{SD}(\mathrm{n}=6)$. Extract buffer components were corrected for the nitrite in the $\mathrm{PO} 4$ buffer, and the complete extract buffer value is the sum of the nitrite in the components and the $\mathrm{PO}_{4}$ buffer

\begin{tabular}{|c|c|c|c|}
\hline Reagent blank contents & $\mathrm{nmol} \mathrm{NO}_{2}^{-} \mathrm{ml}^{-1}$ & Volume in blank & $\mathrm{nmol} \mathrm{NO}_{2} \mathrm{ml}^{-1}$ of final reagent blank \\
\hline $\mathrm{PO}_{4}$ buffer $(200 \mathrm{mM})$ & $0.193(0.004)$ & $250 \mu \mathrm{l}$ & 0.016 \\
\hline Zinc acetate $(550 \mathrm{mM})$ & 0 & $2 \mathrm{ml}$ & 0.000 \\
\hline NADH $(0.2 \mathrm{mM})$ in buffer & $0.252(0.005)$ & $100 \mu \mathrm{l}$ & 0.008 \\
\hline FAD $(0.05 \mathrm{mM})$ in buffer & $0.257(0.029)$ & $100 \mu \mathrm{l}$ & 0.009 \\
\hline $\mathrm{KNO}_{3}(20 \mathrm{mM})$ in buffer & $0.468(0.014)$ & $250 \mu 1$ & 0.039 \\
\hline $\begin{array}{l}\text { Extract buffer components } \\
0.03 \% \text { DTT } \\
0.3 \% \text { PVP } \\
0.1 \% \text { Triton } X-100 \\
5 \mathrm{mM} \text { EDTA } \\
3 \% \text { BSA }\end{array}$ & $\begin{array}{l}0.007(0.001) \\
0.047(0.006) \\
0.007(0.000) \\
0.037(0.005) \\
0.427(0.010)\end{array}$ & & \\
\hline $\begin{array}{l}\text { Complete extract buffer } \\
\text { DTT, PVP, Triton X-100, } \\
\text { EDTA, and BSA in } \mathrm{PO}_{4} \text { buffer }\end{array}$ & 0.718 & $300 \mu \mathrm{l}$ & 0.072 \\
\hline Total & & $3 \mathrm{ml}$ & 0.144 \\
\hline Average reagent blank & & & $0.170 \pm 0.082$ \\
\hline
\end{tabular}




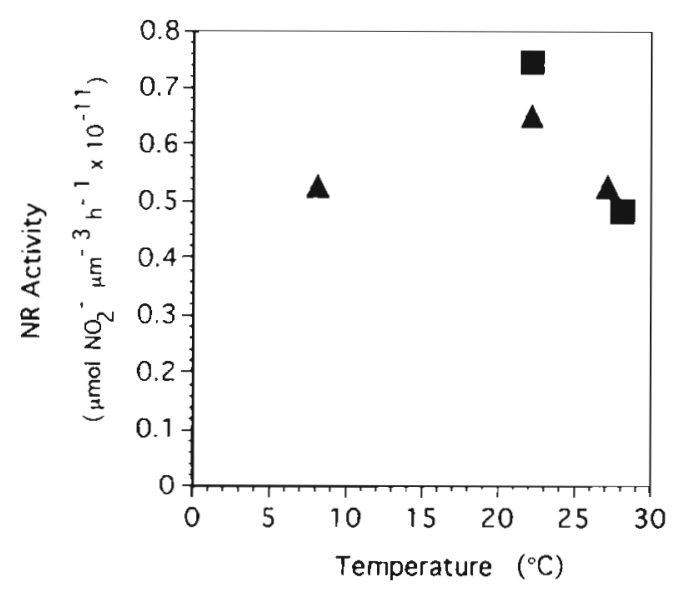

Fig. 3. Effect of temperature on NR activity in 2 pooled samples of Rhizosolenia mats. (ロ) NR2; (A) NR3

$0.05 \mathrm{mM}$ FAD and $10 \mathrm{mM} \mathrm{KNO}_{3}$, addition of $\mathrm{NADH}$ had a similar effect, increasing activity 4 -fold over the assay with no NADH (Fig. 4B). The concentrations of FAD and NADH that yielded the highest activities were 0.05 and $0.2 \mathrm{mM}$, respectively, and were used in all subsequent mat assays. Using chemiluminescence, we detected $\mathrm{NR}$ activity with no $\mathrm{KNO}_{3}$ added to the reaction mixture. This was probably due to the internal nitrate pools present in the cells. Activity increased with the addition of $\mathrm{KNO}_{3}$, but concentrations above $10 \mathrm{mM}$ did not significantly increase activity (Fig. 4C). Since 10 and $50 \mathrm{mM} \mathrm{KNO}_{3}$ worked equally well, with no artificial enhancement of activity noted at the higher nitrate concentration, all later assays contained $50 \mathrm{mM} \mathrm{KNO}_{3}$.

Individual mat assays revealed significant mat-tomat variation in addition to differences between floating and sinking mats (Table 2). To minimize the effects of any diel fluctuations, the data comparing floating and sinking mats were restricted to assays run between 10:00 and 15:00 h. The average chl a per mat was not significantly different between floating mats $(1.02 \pm 0.18 \mu \mathrm{g})$ and sinking mats $(0.79 \pm 0.23 \mu \mathrm{g})$. However, the average internal nitrate concentrations for floating mats $(23.70 \pm 5.64 \mathrm{mM})$ and sinking mats $(4.76 \pm 2.47 \mathrm{mM})$ were significantly different $(\mathrm{p}<0.01)$. NR activity was highly variable in both floating and sinking mats, but was significantly different between the 2 groups when normalized to both chl a ( $\mathrm{p}<$ $0.0003)$ and plasma volume $(p<0.003)$.

Individual Rhizosolenia mat assays also revealed diel variation in NR activity (Fig. 5). Since variability was great at all times of the day, activity of floating mats was averaged over 3 h periods. The average activity for floating mats was $1.35 \times 10^{-11} \pm 2.34 \times 10^{-12} \mu \mathrm{mol} \mathrm{NO}{ }_{2}^{-} \mu \mathrm{m}^{-3}$ $\mathrm{h}^{-1}$ Lowest activity was noted from 21:00 to $24: 00 \mathrm{~h}$ $\left(3.29 \times 10^{-12} \pm 3.13 \times 10^{-12} \mu \mathrm{mol} \mathrm{NO} \mathrm{NO}_{2}^{-} \mu \mathrm{m}^{-3} \mathrm{~h}^{-1}\right)$, and highest activity was found between $13: 00$ and 16:00 h
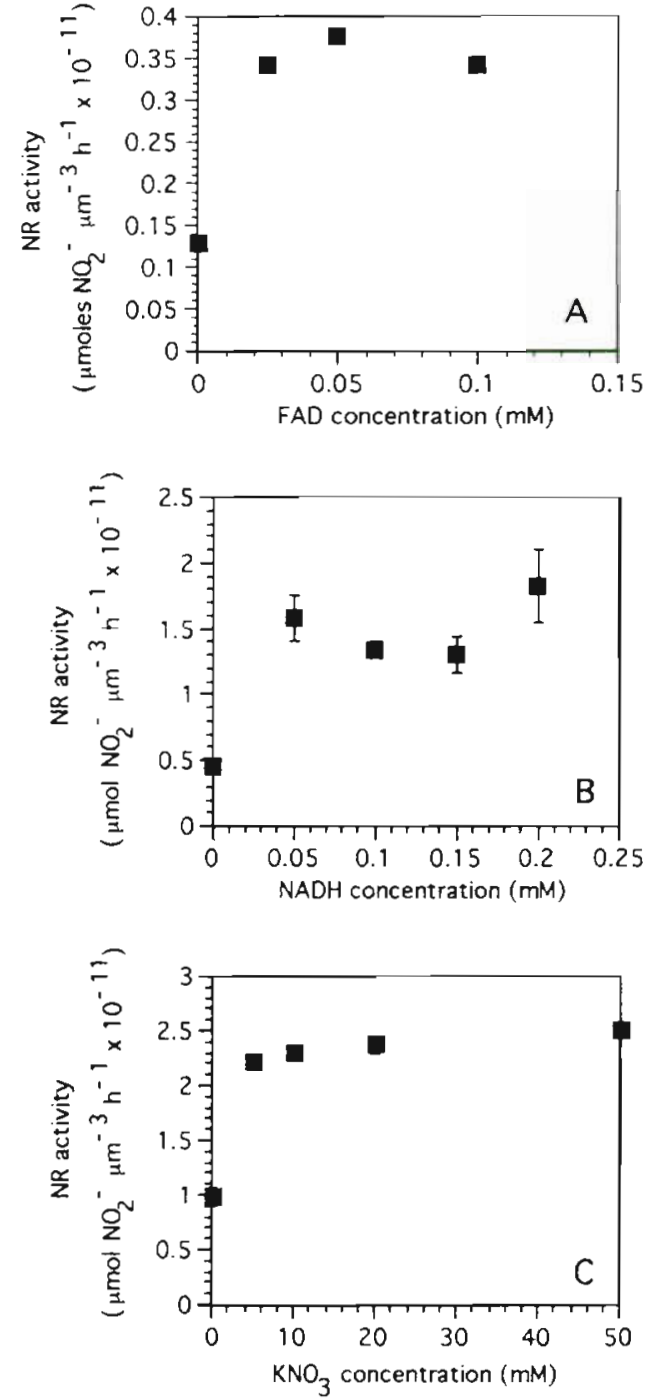

Fig. 4. Effects of (A) FAD, (B) NADH, and (C) $\mathrm{KNO}_{3}$ concentrations on NR activity of Rhizosolenia mats. Error bars are the range of duplicate injections. In $(C)$, the nitrate concentration when no $\mathrm{KNO}_{3}$ was added was actually $0.13 \mathrm{mM}$ due to the internal nitrate of the Rhizosolenia cells

$\left(2.22 \times 10^{-11} \pm 5.59 \times 10^{-12} \mu \mathrm{mol} \mathrm{NO}_{2}^{-} \mu \mathrm{m}^{-3} \mathrm{~h}^{-1}\right)$. The afternoon (13:00 to $16: 00 \mathrm{~h})$ and late afternoon-evening (17:00 to 20:00 h) values were significantly different from each other $(p<0.05)$. These values and the data presented in Table 2 and Fig. 5 do not include 2 anomalous noon assays in which no activity could be detected.

\section{DISCUSSION}

\section{NR assay}

Our data confirm previous reports (Berges \& Harrison 1995) of taxon-specific differences in the optimal 
Table 2. Comparison of individual floating and sinkung mat INC (internal nitrate concentration), chl a content, and NR activity normalized to both chl a and plasma volume. All assays were run between 10:00 and 15:00 h

\begin{tabular}{|c|c|c|c|c|}
\hline & $\operatorname{INC}(\mathrm{mM})$ & $\mu \mathrm{g}$ chl a mat ${ }^{-1}$ & $\mu \mathrm{mol} \mathrm{NO} \mathrm{Ng}_{2}{ }^{-1} \mathrm{chl} a \mathrm{~h}$ & $\mu \mathrm{mol} \mathrm{NO}{ }_{2} \mu \mathrm{m}^{3} \mathrm{~h}^{-1}$ \\
\hline \multirow[t]{14}{*}{ Floaters } & $3.80^{\mathrm{a}}$ & 2.20 & 0.0253 & $1.47 \times 10^{-11}$ \\
\hline & $7.68^{\circ}$ & 2.28 & 0.0230 & $1.22 \times 10^{-11}$ \\
\hline & $15.87^{d}$ & 1.58 & 0.0185 & $0.95 \times 10^{-11}$ \\
\hline & $29.73^{a}$ & 0.59 & 0.0120 & $0.82 \times 10^{-11}$ \\
\hline & $3.96^{\mathrm{a}}$ & 1.29 & 0.0050 & $0.39 \times 10^{-11}$ \\
\hline & $31.68^{\circ}$ & 0.22 & 0.0310 & $6.20 \times 10^{-11}$ \\
\hline & $23.09^{\mathrm{at}}$ & 0.43 & 0.0520 & $2.54 \times 10^{-11}$ \\
\hline & $39.66^{\mathrm{a}}$ & 0.74 & 0.0330 & $1.85 \times 10^{-11}$ \\
\hline & $2.19^{a}$ & 0.41 & 0.0130 & $1.09 \times 10^{-11}$ \\
\hline & $11.39^{4}$ & 0.22 & 0.0310 & $3.07 \times 10^{-11}$ \\
\hline & $75.86^{a}$ & 0.78 & 0.0300 & $3.75 \times 10^{-11}$ \\
\hline & 50.28 & 0.84 & 0.0081 & $2.06 \times 10^{-11}$ \\
\hline & 28.90 & 1.59 & 0.0060 & $0.92 \times 10^{-11}$ \\
\hline & 7.77 & 1.10 & 0.0100 & $1.50 \times 10^{-11}$ \\
\hline Average & 23.70 & 1.02 & 0.0213 & $1.99 \times 10^{-11}$ \\
\hline SE & 5.64 & 0.18 & 0.0036 & $0.41 \times 10^{-11}$ \\
\hline \multirow[t]{4}{*}{ Sinkers } & $11.40^{\circ}$ & 0.54 & 0.0036 & $0.05 \times 10^{-11}$ \\
\hline & $5.63^{\circ}$ & 0.54 & 0.0055 & $0.87 \times 10^{-11}$ \\
\hline & $0.60^{a}$ & 1.48 & 0.0004 & $0.02 \times 10^{-11}$ \\
\hline & $1.42^{\mathrm{a}}$ & 0.61 & 0.0051 & $0.37 \times 10^{-11}$ \\
\hline Average & 4.76 & 0.79 & 0.0037 & $0.33 \times 10^{-11}$ \\
\hline $\mathrm{SE}$ & 2.47 & 0.23 & 0.0012 & $0.20 \times 10^{-11}$ \\
\hline
\end{tabular}

reagent protocol for NR determination. Gao et al. (1993) noted structural differences among phytoplankton NR, and presumably these differences are related to the assay specificity requirements. While the assay has great use for understanding nitrogen assimilation patterns, quantitative results cannot be obtained without critical evaluation of both the reagent assay mixture and incubation temperature.

Although Rhizosolenia mats are multiple species assemblages, we consider them as distinct entities, and optimization experiments were assumed to be valid for all mats. Differences among species within mats were likely not very significant, as the differences between optimal mat and $R$. setigera reagent mixtures were not major. Optimal temperature varied considerably between Rhizosolenia mats and $R$, setigera (data not shown). R. setigera had an optimal assay temperature of $14^{\circ} \mathrm{C}$, similar to its optimal growth temperature. This reflects previous observations indicating growth temperature as the optimal incubation temperature (Gao et al. 1993). Berges \& Harrison
(1995) also suggested running the assay at the temperature at which the cells had been grown. The temperatures examined for mats in this study were limited due to conditions in the field, and we chose to run

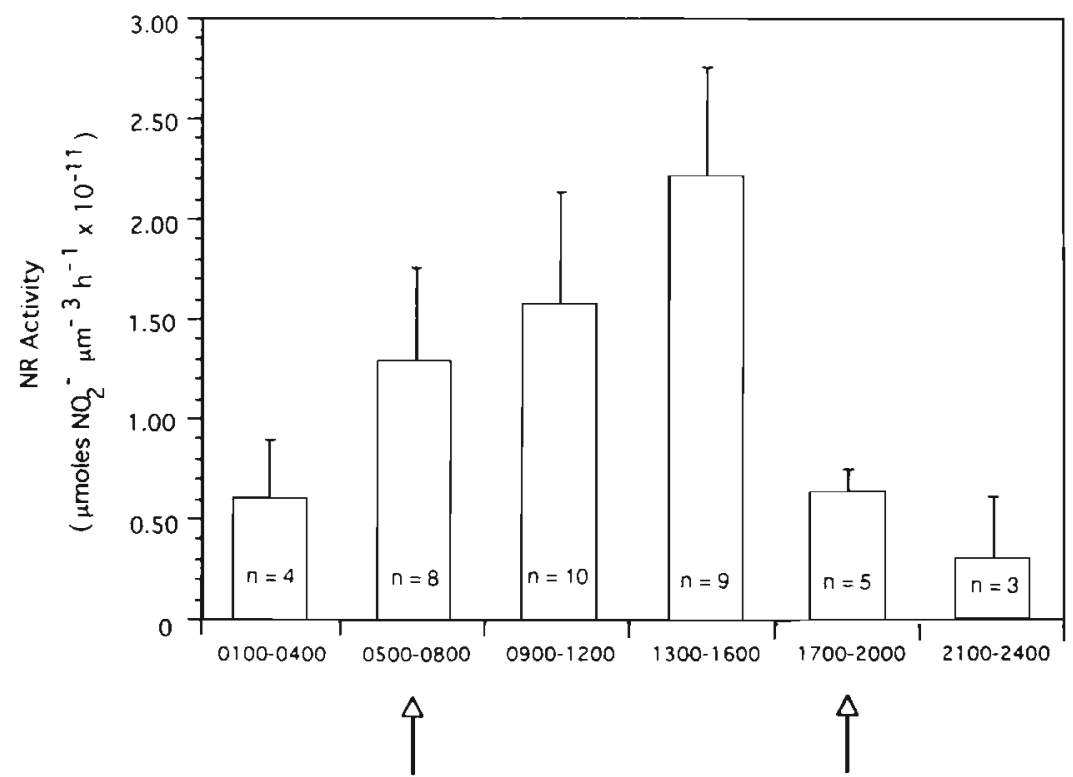

Fig. 5. NR activity of floating mats averaged over 3 h periods. Error bars represent SE, $\mathrm{n}=$ number of mats assayed. Arrows indicate approximate times of sunrise and sunset $(07: 00$ and 20:00 h) 
assays at room temperature because it yielded the highest activity. We cannot explain why the surface temperature did not prove to be the best, but it could be because the deckboard incubator $\left(27\right.$ to $\left.28^{\circ} \mathrm{C}\right)$ was slightly warmer than the average temperature of the surface water $\left(25\right.$ to $26^{\circ} \mathrm{C}$ ). It is also possible that Rhizosolenia mats are adapted to varying temperatures, as they are exposed to a wide range of temperatures in the course of their vertical migration. On this cruise, the average temperature of the surface water was 25 to $26^{\circ} \mathrm{C}$, while the temperature at the depth of the nutricline $\left(80\right.$ to $100 \mathrm{~m}$ ) was typically 17 to $20^{\circ} \mathrm{C}$.

Although neither Eppley's (1978) nor Berges \& Harrison's (1995) protocol calls for FAD, we found that addition of FAD greatly increased NR activity in both Rhizosolenia setigera (data not shown) and Rhizosolenia mats. FAD is one of the enzyme cofactors that mediate electron transfer in the 2-electron reduction of nitrate to nitrite. It is noncovalently bound to the enzyme and easily dissociable from the nitrate reductase of Neurospora crassa, yet very tightly bound in other nitrate reductases (Dunn-Coleman et al. 1984). Everest et al. (1984) found that the addition of FAD was required for maximum NR activity in a number of marine algae. However, Berges \& Harrison (1995) found that addition of FAD affected the NR activity differently for each of the 3 taxa they examined, and advised against its use unless its effects are examined for a particular species.

Alldredge \& Silver (1982) reported the presence of bacterial endosymbionts in Rhizosolenia mats. Bacteria are a potential source of $N R$, presenting the possibility that by adding FAD, we in fact measured bacterial NR activity. Bacterial NR cannot use NADH as an electron donor, but it may be able to use reduced ferredoxin (Guerrero et al. 1981). We added an oxidized form of FAD, which could not serve as an electron donor. Therefore, we feel it is unlikely that the NR activity we measured was from bacterial endosymbionts, and that the FAD served only as an enzyme stabilizer.

In optimizing the $\mathrm{KNO}_{3}$ concentration for Rhizosolenia mats, we detected $\mathrm{NR}$ activity when no $\mathrm{KNO}_{3}$ had been added. The cellular nitrate of the 2 mats pooled for this experiment would have resulted in a reaction mixture concentration of $0.13 \mathrm{mM}$ nitrate. This concentration is sufficient to account for the $3 \mathrm{nmol}$ of $\mathrm{NO}_{2}$ produced by the reaction, but was too low to yield the maximum reduction rate.

Berges \& Harrison (1995) quantitatively related NR activity to actual nitrogen incorporation into the cells, as calculated by growth rates and the cell nitrogen quota, in 5 species of diatoms examined. Overall, the NR assay appeared to work well for Rhizosolenia mats, but the small size of the mats limits the different analyses that can be made on each mat, and the variability among mats discourages pooling data. However, calculations suggest that the NR rates we obtained are sufficient to account for previously reported estimates of mat growth rates. Previous research has found that internal nitrate pools represent approximately half of the total nitrogen present in ascending mats (Villareal et al. 1996). The highest INC we measured in a floating mat for which no contamination was suspected was $50.28 \mathrm{mM}$ (Table 2). This mat contained a total of 156 nmol $\mathrm{NO}_{3}{ }^{-}$. NR activity for the mat as a whole was 6.8 nmol $\mathrm{NO}_{2}^{-}$produced $\mathrm{h}^{-1}$. Assuming the rate for this mat was constant, the particulate nitrogen would be doubled in $23 \mathrm{~h}$. This is probably an underestimate of the nitrogen doubling time as it does not consider any reduction of NR activity due to diel fluctuations or decreasing nitrate pools. Carbon doubling times of $29.5 \mathrm{~h}$ for Rhizosolenia mats have been reported based on $\mathrm{O}_{2}$ evolution experiments (Villareal et al. 1996). The agreement of these 2 estimates suggests that NR activity may be adequate to supply the mats' total nitrogen demands.

\section{Chemiluminescent $\mathrm{NO}_{2}^{-}$determination}

Chemiluminescent and colorimetric determination of nitrite are both easy and reliable methods well suited for use with this NR assay. Both techniques provide a quick analysis of samples and can be easily performed in the field. Samples can be processed immediately and continuously, permitting near real-time profiles. However, the limits of colorimetric detection resulted in Eppley's (1978) suggestion that at least $10 \mu \mathrm{g}$ chl a be used to obtain a strong signal. Using chemiluminescent nitrite determination, we have detected NR activity in as little as $0.2 \mu \mathrm{g}$ chl $a$, increasing the power of the assay by 50 -fold. This lower biomass requirement allows for more discrete or defined sampling, as in the ability to assay individual Rhizosolenia mats. It is an advantage in laboratory experiments by allowing repeated sampling from the same culture, and in the field by requiring the filtration of much less water when assaying natural assemblages.

Chemiluminescence has several advantages over colorimetric nitrite determination. Since the analysis is instantaneous, the assay mixture can be injected directly into the reaction flask at the time desired, eliminating the need to stop the reaction with zinc acetate and then centrifuge the final sample. Similarly, a greater amount of the enzyme extract could be used in the assay and the time zero sample withdrawn and analyzed immediately rather than having 2 separate assay mixtures. In addition, chemiluminescent $\mathrm{NO}_{2}$ detection is not constrained by a fixed sample volume. This is a considerable advantage over the fixed path- 
length of spectrophotometers and autoanalyzers. Although there is a lower limit on the amount of nitrite that chemiluminescence can detect, increased assay sensitivity can be achieved by injecting a greater sample volume. With the ability to detect as little as $0.1 \mathrm{nmol}$ of $\mathrm{NO}_{2}^{-}$, injecting the full $3 \mathrm{ml}$ of a sample would provide a theoretical sensitivity threshold of approximately $30 \mathrm{nM}$.

Increased sensitivity, the greatest advantage of chemiluminescence, is also responsible for some of the technique's drawbacks. We found that reagent blanks and time zero samples contained 0.1 to $0.2 \mathrm{nmol} \mathrm{NO}_{2}$ per $1 \mathrm{ml}$ injection due to trace $\mathrm{NO}_{2}^{-}$in the individual assay reagents. Working in a lower range of $\mathrm{NO}_{2}{ }^{-}$concentrations also makes the analysis vulnerable to trace contamination by containers. In addition, the equipment is expensive and subject to atmospheric contamination.

Chemiluminescence is not the only alternative for low level $\mathrm{NO}_{2}{ }^{-}$determinations. Kieber \& Seaton (1995) report subnanomolar nitrite concentrations in seawater using HPLC analysis of nitrite by derivatization with 2,4-dinitrophenylhydrazine (2,4-DNPH). Potential interference of the assay reagents should be investigated before integrating this method into the NR assay.

\section{Rhizosolenia mats}

The life strategy of Rhizosolenia mats is a repeating cycle of steps: migration to the nutricline, uptake of nitrate, and migration back into the euphotic zone, where presumably the majority of nitrate reduction, photosynthesis, and cell division occurs. There is no evidence to suggest that migration by the entire population is synchronous. We found mats representative of a range of points in the migration cycle, as evidenced by the great variation found in cellular nitrate concentration and NR activity. The floating/sinking classification is based on the mats' appearance in a collection bottle and artificially bifurcates a population which is better represented as a continuum. Rhizosolenia mat INC data illustrate this, and are similar to the continuum of single cell INCs reported for large vertically migrating diatoms in the Sargasso Sea (Villareal \& Lipschultz 1995).

Nevertheless, we found that there were significant differences in the INC and NR activity of floating and sinking mats. Sinking mats displayed an average INC which was $20 \%$ and NR activity which was 16 to $17 \%$ of that found in floating mats. These averages are not true estimates of individual floating or sinking mats, but are useful for illustrating the differences between the extremes. The important point is that substantive differences in nitrogen use occurred. Villareal et al. (1996) noted an elevated C:N ratio, lower protein:car- bohydrate ratio, and lower INC in sinking mats compared to floating mats, suggesting nitrogen as a key limiting nutrient. Our data reinforce this notion since they clearly show diminishing activity of the nitrate incorporation pathways in negatively buoyant mats

Numerous studies have produced evidence of diel and diurnal cycles in NR activity in some higher plants, macroalgae, and planktonic algae (Beevers \& Hageman 1969, Packard \& Blasco 1974, Hersey \& Swift 1976, Martinez et al. 1987, Gao et al. 1992). NR activity displays low values before the light period begins, a rapid increase with the beginning of the light period, a midday maximum, and an afternoon-evening decrease. All studies reported a sustained minimal level of activity in darkness. Our observations followed this pattern as well. The various physical states of the mats we assayed complicated a quantitative interpretation of the diel variation in mat NR activity. Grouping the data into $3 \mathrm{~h}$ blocks removes detail, but diel variation clearly exists. Even presented in this way, maximum afternoon values are significantly different from the late afternoon-evening decrease in activity $(p<0.05)$. We found persistent nighttime NR activity in mats, but it is unclear whether this is a measure of actual dark $\mathrm{NO}_{3}{ }^{-}$reduction, or just activation of the reduction capacity. Isolating the influence of the diel cycle on mat NR activity is necessary to approximate a rate of nitrogen incorporation, but requires a controlled laboratory environment. We have no explanation for 2 floating mat assays in which no activity was detected despite significant cellular nitrate pools (13 and $27 \mathrm{mM}$ ).

Surface nitrate concentrations were frequently $<5 \mathrm{nM}$ in the North Pacific gyre, yet the detection of NR activity indicates that mats are utilizing nitrate. The difference in INC between floating and sinking mats suggests that assimilation is uncoupled from uptake while mats are at the surface, resulting in unbalanced growth. These observations are consistent with our previous understanding of vertical migration in diatoms (Villareal et al. 1993, 1996, Villareal \& Lipschultz 1995), and follow general patterns established for vertically migrating dinoflagellates (Cullen et al. 1985, Ballek \& Swift 1986).

Acknowledgements. This work was supported by NSF grants OCE-5-22858 (T.A.V.) and OCE-94-23561 (F.L.). We thank the officers and the crew of the RV 'Moana Wave' for their assistance in our diving operations, John Berges for his help with the enzyme assay, and Karen Culver-Rymsza for comments on the manuscript.

\section{LITERATURE CITED}

Alldredge AL, Silver MW (1982) Abundance and production rates of floating diatom mats (Rhizosolenia castracanei and $R$. imbricata var. shrubsolei) in the eastern Pacific Ocean. Mar Biol 66:83-88 
Ballek RW, Swift E (1986) Nutrient- and light-mediated buoyancy control of the oceanic non-motile dinoflagellate Pyrocystis noctiluca Murray ex Haeckel (1890). J Exp Mar Biol Ecol 101:175-192

Beevers L, Hageman RH (1969) Nitrate reduction in higher plants. Annu Rev Plant Physiol 20:495-522

Berges JA, Harrison PJ (1995) Nitrate reductase activity quantitatively predicts the rate of nitrate incorporation under steady state light limitation: a revised assay and characterization of the enzyme in three species of marine phytoplankton. Limnol Oceanogr 40:82-93

Blasco D, MacIsaac JJ, Packard TT, Dugdale RC (1984) Relationship between nitrate reductase and nitrate uptake in phytoplankton in the Peru upwelling region. Limnol Oceanogr 29:275-286

Carpenter EJ, Harbison GR, Madin LP, Swanberg NR, Biggs DC, Hulburt EM, McAlister VL, McCarthy JJ (1977) Rhizosolenia mats. Limnol Oceanogr 22:739-741

Chisholm SW (1992) Phytoplankton size. In: Falkowski PG. Woodhead AD (eds) Primary production and biogeochemical cycles in the sea. Plenum Press, New York, p 213-237

Collos Y, Lewin J (1974) Blooms of surf-zone diatoms along the coast of the Olympic Peninsula, Washington. IV. Nitrate reductase activity in natural populations and laboratory cultures of Chaetoceros armatum and Asterionella socialis. Mar Biol 25:213-221

Collos Y, Slawyk G (1976) Significance of cellular nitrate content in natural populations of marine phytoplankton growing in shipboard cultures. Mar Biol 34:27-32

Collos Y, Slawyk G (1977) Nitrate reductase activity as a function of in situ nitrate uptake and environmental factors of euphotic zone profiles. J Exp Mar Biol Ecol 29: $119-130$

Cullen JJ, Zhu M, Davis RF, Pierson DC (1985) Vertical migration, carbohydrate synthesis, and nocturnal nitrate uptake during growth of Heterocapsa niei in a laboratory water column. In: Anderson DM, White AW, Baden DG (eds) Toxic dinoflagellates. Elsevier Science Publishing Co, New York, p 189-194

Dortch Q, Ahmed SI, Packard TT (1979) Nitrate reductase and glutamate dehydrogenase activities in Skeletonema costatum as measures of nitrogen assimilation rates. J Plankton Res 1:169-186

Dunn-Coleman NS, Smarrellı J Jr, Garrett RH (1984) Nitrate assimilation in eukaryotic cells. In: Danielli JF (ed) International review of cytology, Vol 92. Academic Press, New York, p 1-50

Eppley RW (1978) Nitrate reductase in marine phytoplankton. In: Hellebust JA, Craigie JS (eds) Handbook of phycological methods. Cambridge University Press, Cambridge, p $217-223$

Eppley RW, Coalsworth JL, Solórzano L (1969) Studies of nitrate reductase in marine phytoplankton. Limnol Oceanogr 14:194-205

Everest SA, Hipkin CR, Syrett PJ (1984) The effect of phosphate and flavin adenine dinucleotide on nitrate reductase activity of some unicellular marine algae. J Exp Mar Biol Ecol 76:263-275

Gao Y, Smith GJ, Alberte RS (1992) Light regulation of nitrate reductase in Ulva fenestrata (Chlorophyceae). I. Influence of light regimes on nitrate reductase activity. Mar Biol 112 : 691-696

Gao Y, Smith GJ, Alberte RS (1993) Nitrate reductase from the marine diatom Skeletonema costatum. Biochemical and immunological characterization. Plant Physiol 103: $1437-1445$
Garside C (1982) A chemiluminescent technique for the determination of nanomolar concentrations of nitrate and nitrite in seawater Mar Chem 11:159-167

Guerrero MG, Vega JM, Losada $M$ (1981) The assimilator: nitrate-reducing system and its regulation. Annu Rcs Plant Physiol 32:169-204

Hersey RL, Swift E (1976) Nitrate reductase activity of Amphidinium carteri and Cachonina niei (Dinophyceae) in batch culture: diel periodicity and effects of light intensity and ammonia. J Phycol 12:36-44

Hochman A, Nissany A, Wynne D, Kaplan B, Berman T (1986) Nitrate reductase: an improved assay method for phytoplankton. J Plankton Res 8:385-392

Kieber RJ, Seaton PJ (1995) Determination of subnanomolar concentrations of nitrite in natural waters. Analyt Chem $67: 3261-3264$

Martinez R, Packard TT, Blasco D (1987) Light effects and diel variations of nitrate reductase activity in phytoplankton from the northwest Africa upwelling region. Deep Sea Res $34: 741-753$

McCarthy JJ, Carpenter EJ (1983) Nitrogen cycling in nearsurface waters of the open ocean. In: Carpenter EJ, Capone DG (eds) Nitrogen in the marine environment. Academic Press, New York, p 487-512

Packard TT (1973) The light dependence of nitrate reductase in marine phytoplankton. Limnol Oceanogr 18:466-469

Packard TT, Blasco D (1974) Nitrate reductase activity in upwelling regions. 2. Ammonia and light dependence. Tethys 6:269-280

Ramalho CB, Hastings JW, Colepicolo P (1995) Circadian oscillation of nitrate reductase activity in Gonyaulax polyedra is due to changes in cellular protein levels. Plant Physiol 107:225-231

Ryther JH, Dunstan WM (1971) Nitrogen, phosphorus, and eutrophication in the coastal marine environment. Science 171:1008-1013

Scholl RL, Harper JE, Hageman RH (1974) Improvements of the nitrite color development in assays of nitrate reductase by phenazine methosulfate and zinc acetate. Plant Physiol $53: 825-828$

Slawyk G, Collos Y (1976) An automated assay for the determination of nitrate reductase in marine phytoplankton. Mar Biol 34:23-26

Smayda TJ (1978) From phytoplankters to biomass. In: Sourni.a A (ed) Monographs on oceanographic methodology. Vol 6. Phytoplankton manual. UNESCO, Paris, p 273-279

Venrick EL (1969) The distribution and ecology of oceanic diatoms in the North Pacific. PhD dissertation, University of California, San Diego

Villareal TA, Altabet MA, Culver-Rymsza K (1993) Nitrogen transport by vertically migrating diatoms mats in the North Pacific Ocean. Nature 363:709-712

Villareal TA, Carpenter EJ (1989) Nitrogen fixation, suspension characteristics, and chemical composition of Rhizosolenia mats in the central North Pacific Gyre. Biol Oceanogr 6:327-345

Villareal TA, Lipschultz F (1995) Internal nitrate concentrations in single cells of large phytoplankton from the Sargasso Sea. J Phycol 31:689-696

Villareal TA, Woods S, Moore JK, Culver-Rymsza K (1996) Vertical migration of Rhizosolenia mats and their significance to $\mathrm{NO}_{3}$ fluxes in the central North Pacific gyre. J Plankton Res 18:1103-1121

Welschmeyer NA (1994) Fluorometric analysis of chlorophyll $a$ in the presence of chlorophyll $b$ and pheopigments Limnol Oceanogr 39:1985-1992

Manuscript first received: April 13, 1996

Revised version accepted: September 14, 1996 